\title{
PeBiToSens ${ }^{\mathrm{TM}}$ : A Platform for PBT Screening of Fragrance Ingredients Without Animal Testing
}

\author{
Heike Laue ${ }^{\star a}$, Lu Hostettlera, Gordon Sanders ${ }^{b}$, Georg Kreutzer ${ }^{b}$, and Andreas Natschª
}

\begin{abstract}
The determination of persistence $(P)$, bioaccumulation $(B)$ and toxicity $(T)$ plays a central role in the environmental assessment of chemicals. Persistence is typically evaluated via standard microbial biodegradation tests. Bioaccumulation refers to the accumulation of chemicals in organisms and is usually assessed in fish exposed to the test chemical. Toxicity is determined at three trophic levels, with fish toxicity as the highest trophic level assessed. Thus, animal tests are classically needed for both B and T assessment. In vitro systems based on fish liver cells or liver S9 fractions ('RT-S9 assay') have been recently adopted by OECD to measure the biotransformation rates for the chemicals for B assessment. Biotransformation drives clearance from the body and reduces bioaccumulation. For T assessment, an assay based on in vitro toxicity on fish gill cells has been established ('RTgill-W1 assay'). Here we summarize our findings indicating that these tests are highly predictive for fragrance ingredients, and show with two case studies of our latest new registered substances how we apply these tests in particular during development and also for chemical registration. This platform of tests (PeBiToSens ${ }^{\mathrm{TM}}$ ) could fully replace animal tests in ecotoxicological assessment and is key in the Givaudan Safe by Design ${ }^{\mathrm{TM}}$ approach to develop safer and environmentally compatible novel fragrance ingredients.
\end{abstract}

Keywords: Acute aquatic toxicity · Bioaccumulation · Biodegradation · Ecotoxicity $\cdot$ in vitro

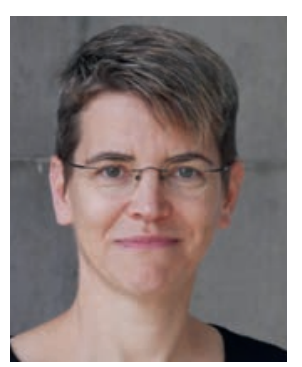

Dr. Heike Laue is a Senior Research Scientist in the In Vitro Molecular Screening team at Givaudan. She joined the team in 2009 and is mainly involved in the development, implementation and validation of alternative methods for environmental safety assessment with particular focus on bioaccumulation. Additional activities are related to the in vitro mammalian metabolism of fragrance ingredients. She received her $\mathrm{PhD}$ degree in Biology from the University of Konstanz (Germany) in 2000 and was a postdoctoral fellow at the Danish Technical University (Denmark) from 2001-2003 working on bacterial biofilms. From 2003 to 2008 she worked at Arpida AG in Reinach $(\mathrm{CH})$ on the development of new anti-infectives.

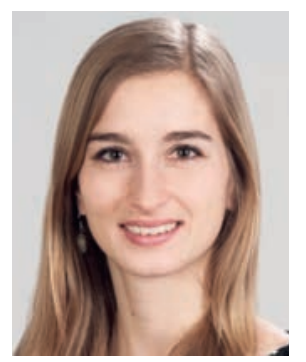

Lu Hostettler holds a Master's degree in Molecular Life Sciences from the University of Bern and joined the In Vitro Molecular Screening team at Givaudan in 2016. Her work focuses on the implementation and application of in vitro assays for the evaluation of novel fragrance ingredients regarding their toxicological and bioaccumulative potential.

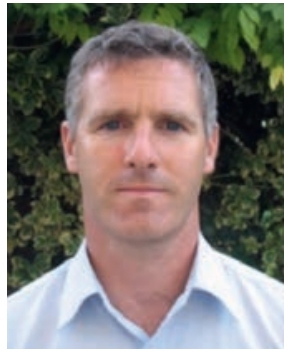

Dr. Gordon Sanders is a Principal Scientist within the Product Safety Sciences group at Givaudan International SA in the Regulatory and Product Safety department focusing on environment, ecotoxicology and external advocacy activities. He has a $\mathrm{PhD}$ in Environmental Sciences and has worked extensively in the plant protection industry specializing in residue studies and laboratory and field environmental fate testing. Prior to joining Givaudan, Gordon spent almost a decade leading the Naturals purchasing group of a major flavor and fragrance company.

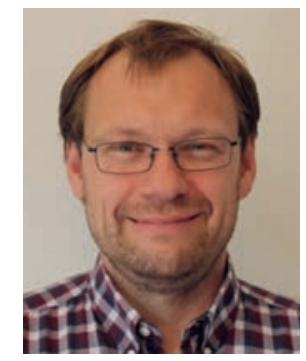

Dr. Georg Kreutzer is a Senior Scientist in the area of environmental fate and ecotoxicology in the Givaudan International SA Regulatory and Product Safety department. He received his PhD degree in chemistry from the University of Regensburg, Germany. After a postdoctoral stay at the Swiss Federal Institute of Technology in Lausanne (EPFL) he joined Givaudan in 2006, first at the Science and Technology department, then specializing in the regulatory testing of fragrance molecules, namely in the phys.-chem. and environmental fate area. 


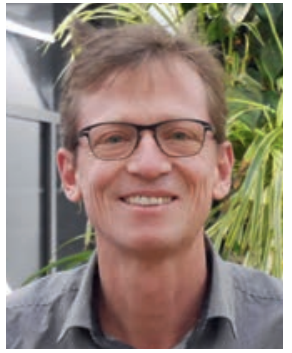

Dr. Andreas Natsch leads the In Vitro Molecular Screening team at Givaudan. The team evaluates risks and bioactivities of novel ingredients early in the development pipeline. He started his career at Givaudan in 1998 and was first involved in the elucidation of the biochemical mechanisms of body odor formation in order to design new deodorant ingredients. In parallel he investigated the biological activities of fragrance raw materials and developed novel formulations, e.g. for preservation of cosmetic products without classical preservatives. Since 2008, the research focus has shifted to the development, validation and implementation of in vitro assays to study toxicological risks associated with cosmetic and fragrance ingredients without using animal testing.

\section{Introduction}

The assessment of the environmental profile is a key aspect for the registration of industrial chemicals under REACH (Registration, Evaluation, Authorization and Restriction of Chemicals) and other legislations, especially for those used in consumer products which may lead to wide dispersive use. The determination of persistence $(\mathrm{P})$, bioaccumulation $(\mathrm{B})$ and toxicity to aquatic species and food webs (T) is summarized as the PBT assessment.

\subsection{Persistence}

Persistence is generally screened by the potential of a chemical to be mineralized by microbial communities present in sewage sludge from water treatment plants or river water, and standardized screening tests have been in use for decades. ${ }^{[1]}$

\subsection{Bioaccumulation}

Bioaccumulation refers to the accumulation of chemicals in organisms and of prime concern is the accumulation in the fat tissues of fish, which may be exposed for a prolonged time to chemicals in environmental water or via the food chain. Bioconcentration refers to uptake of the chemical via water only and is determined based on a standardized test in which fish are exposed to a constant concentration of the chemical in water and the accumulation in the fish tissue is determined. ${ }^{[2]}$ It is expressed as the bioconcentration factor $(\mathrm{BCF})$ which refers to the ratio between the concentration in fish and the concentration in water at steady state. In Europe in the context of PBT assessment for new chemical registrations under REACH, chemicals are considered bioaccumulative if this ratio exceeds the threshold of $2000 \mathrm{~L} / \mathrm{kg} \cdot{ }^{[3]} \mathrm{In}$ absence of biological data, bioaccumulation is often screened (e.g. $\left.\log \mathrm{K}_{\mathrm{ow}}>4.5\right)^{[3]}$ or BCF predicted from the lipophilicity of a chemical expressed as its octanol-water partition coefficient $\left(\log \mathrm{K}_{\mathrm{ow}}\right)$. However, this is a simplified view, as it does not account for the fact that fish are not just a passive sink for chemicals in the environment, but that they have active processes leading to the excretion of chemicals. Especially biotransformation of chemicals by the fish liver is a key factor reducing bioaccumulation. ${ }^{[4]}$

\subsection{Aquatic Toxicity}

Short-term toxicity to aquatic species is assessed at three tropic levels. Toxicity to freshwater algae (phytoplankton) is the first level, and it is assessed routinely by measuring the growth rate of monocellular algae or cyanobacteria exposed to the test chemical for 72 h. ${ }^{[5]}$ Small invertebrates feeding on algae are the next trophic level, hence an immobilization test with e.g. Daphnia magna, an abundant crustacean in freshwater, is the second trophic level assessed. ${ }^{[6]}$ Finally, toxicity to fish as the key aquatic vertebrate needs to be determined, and this is done by exposing fish for $96 \mathrm{~h}$ to the chemical dissolved in water, with lethality and a derived
$\mathrm{LC}_{50}$ as the endpoint determined, ${ }^{[7]}$ and, for animal welfare reasons is only requested from Annex VIII and superior annual tonnages within the REACH testing requirements. When required, and applying the principles of the 3Rs (see Section 2), an in vivo acute fish study would follow the Threshold Approach described in an OECD Guidance Document, ${ }^{[8]}$ which is also recommended in the recent revision of the OECD TG 203 on fish acute toxicity testing. ${ }^{[7]}$ As an alternative to the fish acute toxicity test, the fish embryo acute toxicity test (FET) was proposed. ${ }^{[9,10]}$ Short-term toxicity to fish eggs and hatching embryos, which are considered in many jurisdictions to be a non-protected life stage (i.e. not subject to the same animal welfare considerations as juvenile and adult fish), ${ }^{[11]}$ was shown to correlate well to the toxicity to mature fish, yet this test still needs a source of fish eggs, and there are still certain limitations in its use under REACH. ${ }^{[12]}$

\section{Reducing Animal Testing}

The use of animal testing to determine toxicity of chemicals is increasingly being scrutinized by society. This movement started within the field of cosmetics, as it was felt that no animals should suffer for luxury products solely affecting human well-being and not required for human health like pharmaceuticals. This movement culminated in a ban for animal testing of ingredients solely used in cosmetics in the European Union by 2013. Testing for industrial chemicals is still mandatory and dual-use chemicals, i.e. those used in cosmetics and other applications, may still be tested if required by the regulation for those other applications. Yet, reducing animal testing to a maximal degree has become an imperative and under the REACH regulation vertebrate animal testing should be the last resort. [13] Initially, concerns were mainly focused on toxicity tests conducted on mammals, but regulations treat all vertebrates similarly, and thus replacing animal tests, namely fish tests, is also needed in environmental toxicology. ${ }^{[1]}$ This has led to significant investments and research efforts into the 3Rs, which stand for replacement, reduction, and refinement of animal testing and this concept had been proposed by Russell and Burch in 1959. ${ }^{[14]}$ Here we focus on the first R, the ultimate replacement of animal testing in ecotoxicology, aware of the fact that such assays must fulfil the requirements of an additional 3Rs, i.e. be reproducible/reliable, relevant, and regulatory acceptable. ${ }^{[11]}$

\subsection{Replacing the Need for in vivo BCF Studies by Measuring Biotransformation in vitro}

Bioconcentration of a chemical is the net result of the uptake of the chemical from the water via the gills and elimination processes such as the excretion via the gills, biotransformation, and fecal egestion (Fig. 1). In absence of in vivo BCF data, predictive models are commonly applied which are based on the $\log \mathrm{K}$, i.e. the lipophilicity of the chemical. There is a good linear correlation between the $\log \mathrm{K}_{\text {ow }}$ and the passive bioaccumulation for chemicals with a $\log \mathrm{K}_{\mathrm{ow}}<c a .7$ which are not biotransformed. [15] Biotransformation can reduce the extent to which chemicals accumulate in fish resulting in the formation of metabolites with higher water solubility which can finally be excreted by the organism. Although screening-level QSAR models for estimating biotransformation rates based on chemical structure have been established, ${ }^{[16,17]}$ biotransformation is still considered as one of the major uncertainties in the prediction of bioaccumulation of chemicals in fish.

\subsubsection{The Trout Liver S9 Assay to Measure Biotransformation in vitro}

Recently two in vitro methods have been validated in an international ring trial which are based on liver $\mathrm{S} 9$ sub-cellular fractions (RT-S9) and liver cells (hepatocytes) from rainbow trout.[18] In principle, substrate depletion assays are carried out using either hepatocytes or RT-S9 in the presence of cofactors which are required 


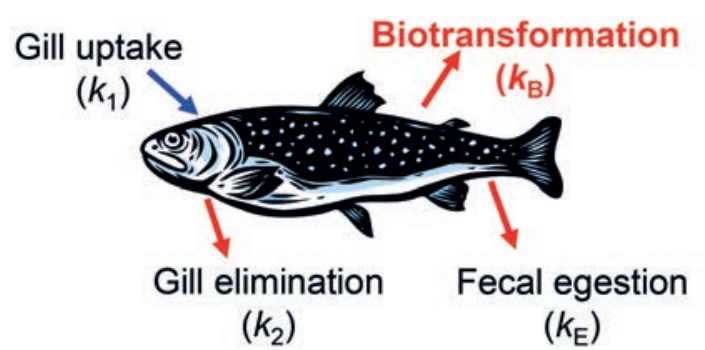

Fig. 1. Processes affecting bioaccumulation and rates used in the BCF prediction model. The chemical is taken up only via the water $\left(k_{1}\right.$, gill uptake rate constant). Biotransformation $\left(k_{\mathrm{s}}\right)$, excretion via the gills $\left(k_{2}\right)$ or feces $\left(k_{\mathrm{E}}\right)$ are parameters which may contribute to a substantial decrease of the chemical in fish. ${ }^{[39]}$

by the biotransformation enzymes and are usually present in intact cells. The decrease of the test chemical is analyzed by analytical methods like GC-MS or LC-MS. Heat inactivated biological material is used as a negative control to evaluate potential abiotic losses like volatilization or adsorption of highly hydrophobic chemicals. Positive controls are also tested to verify the enzymatic activity of the $S$ 9 fractions or heptacytes in the assay. ${ }^{[18]}$ The validation study showed that both assays are highly reliable to determine in vitro biotransformation rates and resulted in their adoption as new test guidelines (TGs) by OECD (OECD TG 319A and B). ${ }^{[19,20]}$ These OECD test guidelines are accompanied by a guidance document which outlines how to use the biotransformation rates to predict BCFs. [21]

\subsubsection{In vitro - in vivo Extrapolation Models to Predict BCFs}

In vitro - in vivo extrapolation (IVIVE) models have been used for decades to predict drug clearance for mammals. ${ }^{[22]}$ These models have been adapted to predict BCFs taking into consideration specific physiological parameters for fish to refine $\mathrm{BCF}$ predictions. The current most commonly used IVIVE model by Nichols et al. ${ }^{[23]}$ predicts the BCF for a standard fish defined as a $10 \mathrm{~g}$ rainbow trout which is held at $15{ }^{\circ} \mathrm{C}$ and contains $5 \%$ whole body lipid. The biotransformation rate determined in the RT-S9 assay is converted into a whole body biotransformation rate constant $\left(k_{\mathrm{B}}\right.$, or referred to as $\left.k_{\mathrm{MET}}\right)$ taking into consideration potential rate limitations by blood flow. The $\log \mathrm{K}_{\mathrm{ow}}$ of the test chemical, either estimated by using QSARs ${ }^{[24]}$ or measured, ${ }^{[25]}$ are additional chemical dependent inputs of the IVIVE model. The model includes also a correction factor (fraction unbound, $f_{\mathrm{U}}$ ) for potential protein binding effects on clearance. ${ }^{[23]} f_{\mathrm{U}}$ is a binding term (ranging from 0 to 1.0) that corrects for the differences in free chemical concentration between blood (in vivo) and the in vitro system. It is based on the assumption that only the free or unbound fraction of the chemical is available for the biotransformation enzymes. The modelled gill uptake rate constant $\left(k_{1}\right)$, the gill elimination rate constant $\left(k_{2}\right)$ and the fecal egestion rate $\left(k_{\mathrm{E}}\right)$ are then combined with the estimated whole body biotransformation rate constant $\left(k_{\mathrm{B}}\right)$ (Fig. 1) to finally predict the $\mathrm{BCF}\left(\mathrm{L} / \mathrm{kg}\right.$ fish). ${ }^{[23]}$

Presently, the effect of chemical binding is one of the major uncertainties in modelled BCF predictions. It was observed in several studies that setting $f_{\mathrm{U}}=1.0$ (i.e. assuming the same availability of the chemical to the biotransformation enzymes in vitro and in vivo) resulted in much better agreement between predicted and measured $\mathrm{BCF}$ values, although setting $f_{\mathrm{U}}=1.0$ is mechanistically not correct. $[18,26,27]$

\subsubsection{Application of the in vitro RT-S9 Assay to Predict BCFs of Fragrance Ingredients}

We have recently expanded our data set to 30 chemicals in total (23 fragrance chemicals) on comparing predicted BCFs based on in vitro $\mathrm{S} 9$ data and in vivo BCFs determined in fish (Laue et al., manuscript in preparation). There is a general tendency of the IVIVE to overpredict the bioaccumulation potential. Predicted $\mathrm{BCF}$ are on average 6.8-fold higher compared to measured in vivo values with $f_{\mathrm{U}}$ calculated and 1.7-fold higher using the assumption $f_{\mathrm{U}}=1.0$. However, setting $f_{\mathrm{U}}=1.0$ resulted in an underestimation of the BCF for five chemicals (by a factor of 3.8 -45). Further studies and modifications of the IVIVE model are needed to improve the predictions. BCFs predicted with the current IVIVE model do avoid the high overpredictions compared to in silico models based solely on $\log \mathrm{K}_{\text {ow }}$ (i.e. no assumed biotransformation).

\subsection{Replacing the Need for Acute Toxicity Studies in Fish: The RTgill-W1 Assay}

The first site of extensive contact of a chemical in water with fish tissue is the gill surface. Many chemicals can lead to lethality of fish if they are able to interact with the membranes of the cells in the gill tissue. Unspecific interaction with cell membranes (as compared to specific toxicity due to e.g. receptor binding or formation of reactive metabolites) is referred to as a narcotic mode of action. ${ }^{[28]}$ This simple mode of action is particularly prevalent among small lipophilic chemicals such as fragrance chemicals. An assay to determine toxicity to fish gill cells ${ }^{[29]}$ has been fully standardized. A static monolayer of the gill cell line RTgill-W1 from rainbow trout is exposed to different test chemical concentrations for $24 \mathrm{~h}$ and cell viability is measured with three different endpoints (metabolic activity assessed by the Alamar blue assay; plasma membrane integrity and lysosomal integrity. ${ }^{[29]}$ It underwent an international validation study ${ }^{[30]}$ to which we participated and it is now proposed for OECD guideline preparation.

To demonstrate applicability of this test, we performed a detailed benchmarking study on 38 fragrance chemicals for which we had historical in vivo data on fish toxicity covering a broad range of physico-chemical properties and varying chemistries. ${ }^{[30]}$ This study showed a very strong correlation between in vitro gill toxicity and in vivo fish toxicity (reproduced in Fig. 2). This correlation is similar for industrial chemicals tested in the validation study and we added the results from our laboratory in the validation trial to Fig. 2 for comparison. We derived regression equations from the dataset of fragrance chemicals using a leave-oneout analysis, and showed that data on 37 fragrance chemicals can predict the toxicity of the left-out chemical with high accuracy: the median fold miss-prediction is 1.5 -fold. ${ }^{[31]}$ This is similar to the error when testing the same chemicals repeatedly in different fish species ${ }^{[10]}$ and it shows the high accuracy of this test to predict toxicity of fragrance ingredients. A final regression equation excluding one outlier - was derived from this dataset as the most appropriate predictive model for fragrance chemicals (Eqn. (1)):

$$
\begin{aligned}
\log \mathrm{LC}_{50} & =0.97( \pm 0.04) \times \\
& \log \mathrm{EC}_{50 \text { PB mean measured }}-0.36( \pm 0.07) \\
& \mathrm{R} 2=0.94
\end{aligned}
$$

where $\mathrm{EC}_{50} \mathrm{~PB}$ mean measured is the exposure concentration reducing cellular viability by $50 \%$ as measured with the PrestoBlue ${ }^{\circledR}(\mathrm{PB})$ assay. The exposure concentration is expressed as the arithmetic mean between the actual concentrations measured at $\mathrm{T}_{0 \mathrm{~h}}$ and $\mathrm{T}_{24 \mathrm{~h}}$ in the test medium. The PrestoBlue ${ }^{\circledR}$ assay is a modification of the standard Alamar blue assay ${ }^{[2,30]}$ and both measure the same endpoint (i.e. metabolic activity of the cells).

In ecotoxicology, concentrations are often expressed as the geometric mean of the measured concentrations at different time points. However, we found that under the exposure conditions of the assay (plastic 24-well plates), the concentration is often declining strongly especially for highly lipophilic chemicals, ${ }^{[31]}$ and using the geometric mean, the low terminal concentration con- 


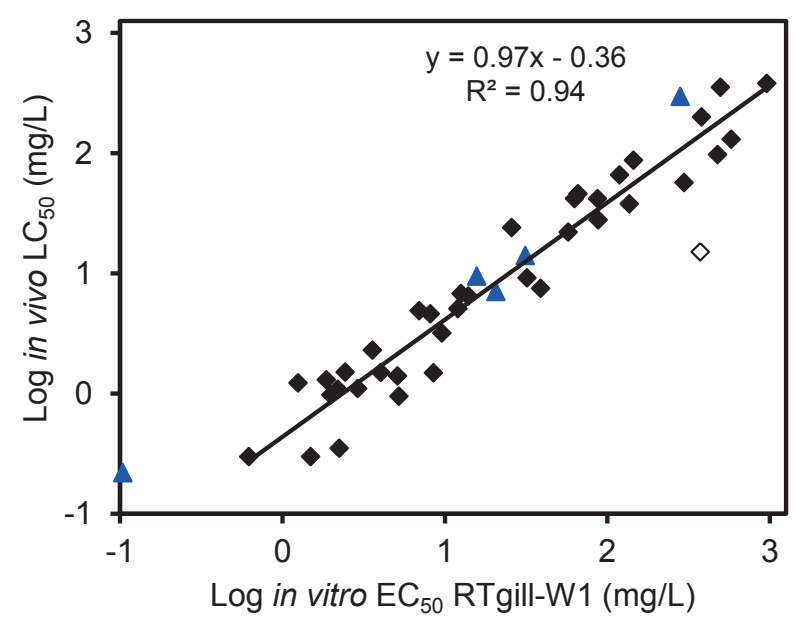

Fig. 2. Correlation between toxicity to RTgill-W1 cells and acute toxicity to fish for fragrance ingredients (black diamonds ${ }^{[31]}$ ) and industrial chemicals tested in the validation study (blue triangles, our data from the ring trial[ $\left.{ }^{[30]}\right)$. The regression line is based on 37 fragrance chemicals (black diamonds) using mean measured concentrations; one outlier was excluded (open diamond). The data set used to build the equation does not include the external test set from the ring trial (blue triangles).

tributes a high weight to the exposure data. As the initial maximal concentration may affect the cells more strongly, we used the arithmetic mean equally weighting the measurements conducted at the start and end of the incubation period for training Eqn. (1) and this approach provides a high accuracy vs. in vivo data.

\section{PeBiToSens ${ }^{\mathrm{TM}}$ - A Platform for Comprehensive Ecotoxicological Screening of Chemicals in the Development Pipeline Without Animal Testing}

Historically, the assessment of mammalian and environmental toxicity was performed rather late in the development of novel industrial chemicals. With increasingly stringent regulations, a safe toxicological profile has become critically important and we have moved the safety assessment of novel ingredients to a very early development stage. The availability of non-animal tests is highly beneficial for this new way of working as it allows inhouse testing for various endpoints at an early stage and helps to select the best candidate molecules and to iteratively improve the design in collaboration with discovery chemists to finally propose chemicals which are Safe by Design ${ }^{\mathrm{TM}}$. This program was initially focusing on mammalian toxicity and culminated in the development of KeratinoSens ${ }^{\mathrm{TM}}$ by our group ${ }^{[32]}$ an assay for testing skin sensitization risk, which was later adopted by the OECD. ${ }^{[33]}$ Integrating the two tests described in the previous section we created an in house platform for a full Persistence, Bioaccumulation and Toxicity screening of chemicals entirely without animal testing, registered under the trade name PeBiToSens ${ }^{\mathrm{TM}}$. For persistency assessment we created a rapid workflow to screen chemicals early in the development pipeline following the OECD TG 301F as briefly described below. ${ }^{[34]}$ The RT-S9-assay combined with IVIVE modeling and measured $\log \mathrm{K}_{\mathrm{ow}}$ is then applied to predict the BCF value. Toxicity is assessed in parallel with a rapid, non-GLP (Good Laboratory Practice) test on Daphnia and algae (which is later followed up with a GLP test for chemical notification purposes), while the RTgill-W1 assay is used for finally predicting fish toxicity. Below we illustrate this approach with two case studies from our most recent market introductions.

\subsection{Case Study 1: Pomelo/ $^{\circledR}$ (2,4,7-Trimethyloct-6-en-1- ol), a Novel Fragrance Ingredient Registered Based on the PeBiToSens ${ }^{\mathrm{TM}}$ Screening}

Pomelol $^{\circledR}(2,4,7$-trimethyloct-6-en-1-ol) is a powerful new floral, rosy note. This chemical was assessed entirely without an- imal tests to determine the ecotoxicological profile for REACH submission in 2017. [35] In the RTgill-W1 assay an $\mathrm{EC}_{50}$ of 11.85 $\mathrm{mg} / \mathrm{L}$ based on mean measured concentration was determined resulting in a predicted fish $\mathrm{LC}_{50}$ of $4.71 \mathrm{mg} / \mathrm{L}$ (Table 1). We have collected in Table 1 a series of related chemicals (alcohols with $10-15$ carbon atoms) from our previous study ${ }^{[31]}$ for which in vivo and in vitro data are available. These data on chemical analogues indicate that the predicted $\mathrm{LC}_{50}$ values for related chemicals are generally in good agreement with the in vivo $\mathrm{LC}_{50}$ values, which further builds confidence in the prediction made for Pomelol ${ }^{\circledR}$. This is clearly a chemical domain where the RTgill-W1 assay appears to have a particularly high predictive applicability. The $\mathrm{EC}_{50}$ determined in the Daphnia magna immobilization assay at $48 \mathrm{~h}$ is $6.4 \mathrm{mg} / \mathrm{L}$, while the $\mathrm{EC}_{50}$ for growth inhibition to algae is 6.1 $\mathrm{mg} / \mathrm{L}$ for yield and $10.8 \mathrm{mg} / \mathrm{L}$ for growth rate. Thus the toxicity at these lower trophic levels is in a very similar range as the value predicted for fish toxicity, which is typical for chemicals mainly acting by a narcotic mode of action and further supports the assessment by the RTgill-W1 assay.

The biotransformation rate of Pomelol ${ }^{\circledR}$ was measured in the RT-S9 assay, and rapid biotransformation was observed for the two major isomers (Fig. 3). Based on the slope of these plots, a biotransformation rate of $5.49 \mathrm{~mL} / \mathrm{h} / \mathrm{mg}$ protein for isomer 1 and $3.91 \mathrm{~mL} / \mathrm{h} / \mathrm{mg}$ protein for isomer 2 was calculated. These rates were entered into the IVIVE model in combination with a measured $\log \mathrm{K}_{\text {ow }}$ of 3.4 for the two major isomers. The predicted BCFs are 52 and $53 \mathrm{~L} / \mathrm{kg}$ using an assumed $f_{\mathrm{U}}=1.0$, while the predicted BCFs are 76 and $82 \mathrm{~L} / \mathrm{kg}$ for the two isomers when accounting for differential binding to protein in the in vitro test and under in vivo conditions ( $f_{\mathrm{U}}$ calculated). These predicted BCFs are substantially below the B criterion of $2000 \mathrm{~L} / \mathrm{kg}$, thus a low bioaccumulation potential is expected for Pomelol ${ }^{\circledR}$.

Finally, an OECD $301 \mathrm{~F}$ ready biodegradation study was performed with Pomelol ${ }^{\circledR}$ using the Manometric Respirometry Test. ${ }^{[34]}$ Mineral medium inoculated with sewage sludge is stirred in presence of the test chemical in a closed flask for 28 days. The consumption of oxygen is measured and the Biological Oxygen Demand, the amount of oxygen taken up by the microbial population during the biodegradation of the test chemical, is expressed as percentage of Theoretical Oxygen Demand (ThOD). The ThOD is calculated from the elemental composition, assuming that carbon is oxidized to carbon dioxide, hydrogen to water and nitrogen to ammonium nitrite or nitrate. Pomelol ${ }^{\circledR}$ was found to be readily biodegradable (Fig. 4). All these data have been submitted to ECHA ${ }^{[35]}$ and they indicate a safe PBT profile for Pomelol ${ }^{\circledR}$, which was determined entirely without animal testing. The overall environmental profile of Pomelol ${ }^{\circledR}$ is shown in Table 2.

\subsection{Case Study 2: Scentaurus ${ }^{\top \mathrm{M}}$ Clean (Ethyl 2-acetyl- 4-methyltridec-2-enoate), a New Fragrance Precursor Registered Based on the PeBiToSens ${ }^{\mathrm{TM}}$ Screening}

Scentaurus $^{\mathrm{TM}}$ Clean (ethyl 2-acetyl-4-methyltridec-2-enoate) is a novel type of fragrance precursor registered under REACH. ${ }^{[36]}$ Such precursors are designed to have a high octanol-water partition coefficient which facilitates deposition of the molecule onto fabric during a laundry cycle and the loss of the fragrance material to the wastewater is minimized. During and after the drying cycle, the fragrant molecule is then released by slow cleavage of the precursor. While this concept intrinsically improves the environmental profile based on atom economy, i.e. by reducing loss into the wastewater, molecules with a high $\log \mathrm{K}_{\mathrm{ow}}$ raise some environmental concerns regarding the potential for bioaccumulation and aquatic toxicity by a narcotic mode of action. Furthermore, poorly soluble chemicals are often rated as difficult-to-test substances. Their very low water solubility makes assessment of aquatic toxicity more challenging. ${ }^{[37]}$ 
Table 1. Toxicity of Pomelol ${ }^{\circledR}$ to RTgill-W1 cells and predicted LC $_{50}$ values according to Eqn. (1) in comparison to related alcohols with available in vivo $\mathrm{LC}_{50}$ values. Data except for Pomelol ${ }^{\circledR}$ are from Natsch et al.

\begin{tabular}{|c|c|c|c|c|c|}
\hline Structure & Name & CAS no. & $\begin{array}{c}\mathrm{EC}_{50} \text { RTgill- } \\
\text { W1 cells }{ }^{\mathrm{a}} \\
(\mathrm{mg} / \mathrm{L})\end{array}$ & $\begin{array}{c}\text { Predicted } \\
\mathrm{LC}_{50}^{\mathrm{b}} \\
(\mathrm{mg} / \mathrm{L})\end{array}$ & $\begin{array}{l}\text { Measured in } \\
\text { vivo } \mathrm{LC}_{50} \\
(\mathrm{mg} / \mathrm{L})^{\mathrm{c}}\end{array}$ \\
\hline & $\begin{array}{c}\text { 2,4,7-trimethyloct-6-en-1-ol } \\
\left(\text { Pomelol }^{\circledR}\right)\end{array}$ & $1913285-57-0$ & 11.85 & 4.71 & no data \\
\hline & $\begin{array}{l}\text { 3,7-dimethyloct-6-en-3-ol } \\
\text { (Dihydrolinalool) }\end{array}$ & $18479-51-1$ & 87.04 & 33.2 & 42 \\
\hline & $\begin{array}{l}\text { 3,7-dimethylocta-1,6-dien-3-ol } \\
\text { (Linalool) }\end{array}$ & $78-70-6$ & 88.2 & 33.7 & 27.8 \\
\hline & $\begin{array}{l}\text { (E)-3,7-dimethylocta-2,6- } \\
\text { dien-1-ol (Geraniol) }\end{array}$ & $106-24-1$ & 57.4 & 22.2 & 22 \\
\hline & $\begin{array}{l}\text { 3-isobutyl-1-methylcyclo- } \\
\left.\text { hexan-1-ol (Rossitol }^{\circledR}\right)\end{array}$ & $215231-33-7$ & 39.04 & 15.3 & 7.5 \\
\hline & $\begin{array}{c}\text { (1-methyl-2-(5-methylhex- } \\
\text { 4-en-2-yl)cyclopropyl)methanol } \\
\left(\text { Rosyfolia }^{\circledR}\right)\end{array}$ & $1655500-83-6$ & 9.6 & 3.9 & 3.2 \\
\hline & $\begin{array}{l}\text { 2-ethyl-4-(2,2,3-trimethyl- } \\
\text { cyclopent-3-en-1-yl)but-2-en-1-ol } \\
\text { (Radjanol) }\end{array}$ & $28219-61-6$ & 2.9 & 1.2 & 1.1 \\
\hline & $\begin{array}{c}\text { 3-methyl-5-(2,2,3-trimethyl- } \\
\text { cyclopent-3-en-1-yl)pent-4-en-2- } \\
\text { ol }\left(\text { Ebanol }^{\circledR}\right)\end{array}$ & 67801-20-1 & 3.6 & 1.51 & 2.3 \\
\hline & $\begin{array}{c}\text { 2-isobutyl-4-methyltetra- } \\
\text { hydro-2H-pyran-4-ol (Florosa) }\end{array}$ & $63500-71-0$ & 497.3 & 180.2 & 354 \\
\hline
\end{tabular}

${ }^{a} \mathrm{EC}_{50}$ values determined in RTgill-W1 cells are based on mean measured concentrations. Values except for Pomelol ${ }^{\circledR}$ have been published previously. ${ }^{[31]}$ ${ }^{b} \mathrm{LC}_{50}$ values were predicted based on the in vitro $\mathrm{EC}_{50}$ values determined in the RTgill-W1 assay using Equation 1 (mean measured concentrations). ${ }^{31]}$ ${ }^{\circ}$ The in vivo fish studies were performed according to OECD TG 203 using different fish species (Cyprinus carpio, Pimephales promelas, Oncorhynchus mykiss, Danio rerio, Lepomis macrochirus).
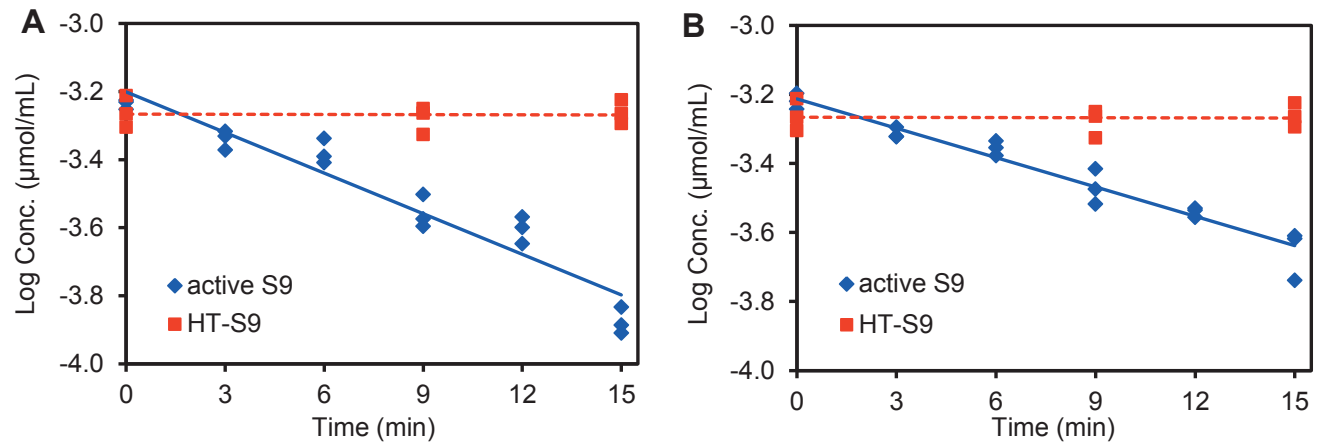

Fig. 3. Biotransformation of the two major isomers of Pomelo ${ }^{\circledR}$ in trout liver S9 sub-cellular fractions (RT-S9). A, Pomelol ${ }^{\circledR}$ Isomer 1 ; B, Pomelol ${ }^{\circledR}$ Isomer 2; closed blue diamonds, active RT-S9 with cofactors added; closed red squares, enzymatically inactive, heat-treated RT-S9 (HT-S9).
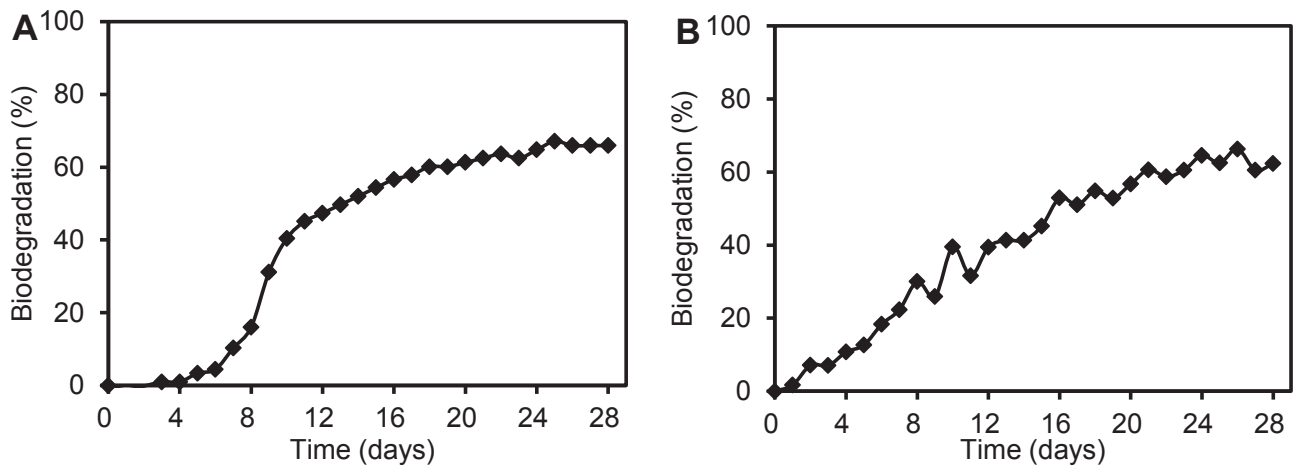

Fig. 4. Biodegradation of Pomelol ${ }^{\circledR}(A)$ and Scentaurus ${ }^{\top M}$ Clean $(B)$ in an OECD $301 \mathrm{~F}$ test. Pomelo ${ }^{\circledR}$ was tested at 30 mg/L, while Scentaurus ${ }^{\mathrm{TM}}$ Clean was tested at $20 \mathrm{mg} / \mathrm{L}$. 
Table 2. Overall environmental profile of Pomelol ${ }^{\circledR}$ and Scentaurus ${ }^{\mathrm{TM}}$ Clean

\begin{tabular}{|c|c|c|c|}
\hline & Assay & Pomelol $^{\circledR}$ & Scentaurus ${ }^{\mathrm{TM}}$ Clean \\
\hline \multicolumn{4}{|l|}{ Chemical structure } \\
\hline CAS no. & & $1913285-57-0$ & $960253-23-0$ \\
\hline $\begin{array}{l}\text { Water solubility } \\
\left(\text { at } 20^{\circ} \mathrm{C}\right)\end{array}$ & OECD $105^{[38]}$ & $101 \mathrm{mg} / \mathrm{L}$ & $0.04 \mathrm{mg} / \mathrm{L}$ \\
\hline $\log \mathrm{K}_{\mathrm{ow}}$ (measured) & OECD $117^{[25]}$ & $\begin{array}{c}3.4 \\
\text { (2 major isomers) }\end{array}$ & $\begin{array}{c}5.3-\sim 6.6^{\mathrm{a}} \\
\text { (major isomers) }\end{array}$ \\
\hline $\begin{array}{l}\text { Persistence } \\
\text { (\% biodegradation) }\end{array}$ & $\begin{array}{l}\text { OECD } 301 F \text { ready biodeg- } \\
\text { radation study }{ }^{[34]}\end{array}$ & $\begin{array}{l}\text { Readily Biodegradable } \\
(66 \%)\end{array}$ & $\begin{array}{l}\text { Readily Biodegradable } \\
\qquad(62 \%)\end{array}$ \\
\hline $\begin{array}{l}\text { Toxicity to algae (measured } \mathrm{EC}_{50} \text { rate; } \\
\left.\left[\mathrm{EC}_{50} \text { yield }\right]\right)^{\mathrm{b}}\end{array}$ & OECD $201^{[5]}$ & $\begin{array}{l}10.8 \mathrm{mg} / \mathrm{L} \\
{[6.1 \mathrm{mg} / \mathrm{L}]}\end{array}$ & $\begin{array}{l}\text { No significant inhibition } \\
\text { of rate [ } 18 \% \text { inhibition of } \\
\text { yield] at water saturation }\end{array}$ \\
\hline $\begin{array}{l}\text { Toxicity to Daphnia magna }\left(\mathrm{EC}_{50}\right. \\
\text { measured) }\end{array}$ & OECD $202^{[6]}$ & $6.4 \mathrm{mg} / \mathrm{L}$ & $\begin{array}{l}\text { No toxicity at water satu- } \\
\text { ration }^{c}\end{array}$ \\
\hline Toxicity to fish (predicted $\mathrm{LC}_{50}$ ) & RTgill-W1 cell line assay & $4.71 \mathrm{mg} / \mathrm{L}$ & $\begin{array}{l}\text { No toxicity at water satu- } \\
\text { ration }^{\text {d }}\end{array}$ \\
\hline Bioaccumulation (predicted BCF) & $\begin{array}{l}\text { RT-S9 test, IVIVE BCF } \\
\text { prediction }{ }^{[20-21]}\end{array}$ & $\begin{array}{l}52-53\left(f_{\mathrm{U}}=1.0\right) \\
76-82\left(f_{\mathrm{U}} \text { calc. }\right)\end{array}$ & $\begin{array}{c}195-285\left(f_{\mathrm{U}}=1.0\right) \\
1341-1548\left(f_{\mathrm{U}} \text { calcu- }\right. \\
\text { lated })^{\mathrm{e}}\end{array}$ \\
\hline
\end{tabular}

aindicative value, peaks are outside calibration domain for HPLC method (OECD TG 117) ${ }^{[25]}$; bendpoints of the algae (Pseudokirchneriella subcapitata) toxicity test are inhibition of the growth rate and inhibition of the yield (biomass at the end of the exposure period minus the biomass at the start of the exposure period) ${ }^{[5]}$; cSince algae and Daphnia toxicity is determined without solvents, the highest concentrations evaluated were at water saturation ( $0.123 \mathrm{mg} / \mathrm{L}$ in algae and Daphnia incubation medium); ${ }^{\mathrm{D}}$ Toxicity to the fish gill cell line RTgill-W1 was tested at water saturation $\left(0.047 \mathrm{mg} / \mathrm{L}\right.$ in the gill cell incubation medium) for Scentaurus ${ }^{\mathrm{TM}}$ Clean. The standard assay procedure of preparing a stock solution in solvent, followed by serial dilutions in aqueous medium was not suitable for this substance as it led to artificially high test concentrations that are above water solubility; ${ }^{\mathrm{B} C \mathrm{BC} s}$ were predicted based on the range of log $\mathrm{K}_{\text {ow }}$ values determined for the major isomers (log $\mathrm{K}_{\text {ow }} 5.3-6.6$ ).

Scentaurus ${ }^{\mathrm{TM}}$ Clean has a water solubility of only $0.04 \mathrm{mg} / \mathrm{L}$ in ultrapure water as tested according to OECD TG 105. ${ }^{[38]}$ When it was tested with the RTgill-W1 assay according to the standard operating procedure, an $\mathrm{EC}_{50}$ of $1.36 \mathrm{mg} / \mathrm{L}$ based on mean measured concentration was found. This concentration is far above water saturation since stock solutions of the test chemical and serial dilutions are prepared in pure solvent (DMSO) and then finally diluted in the test medium (final solvent concentration $0.5 \% \mathrm{v} / \mathrm{v}$ ). ${ }^{[29]}$ However, in ecotoxicology, the toxicity of poorly soluble chemicals is routinely tested up to water saturation only[37] because a result above water saturation is not relevant for risk assessment to the aquatic environment. Therefore, a saturated solution in the medium used for the RTgill-W1 test was prepared according to OECD TG 105. ${ }^{[38]}$ A solubility of $0.047 \mathrm{mg} / \mathrm{L}$ was reached after stirring for 7 days. This saturated solution was then tested in the RTgill-W1 assay, and no toxicity was observed (viability of 92 $\pm 6 \%$ ). Thus it can be concluded that Scentaurus ${ }^{\mathrm{TM}}$ Clean has no toxicity to the gill cells at water saturation. For registration, a test on immobilization of D. magna was conducted also at water saturation. ${ }^{[6]}$ No acute toxic effects were found. The saturation concentration in the Daphnia incubation buffer was even higher $(0.123 \mathrm{mg} / \mathrm{L})$. In a test on microalgae, ${ }^{[5]} 18 \%$ inhibition of yield and no significant inhibition of growth rate was observed in a saturated solution $(0.123 \mathrm{mg} / \mathrm{L}$ in algae incubation buffer $)$, indicating only weak toxicity at the solubility limit.

Scentaurus ${ }^{\mathrm{TM}}$ Clean was tested in the RT-S9 assay and moderate turnover was observed with $84.5 \%$ decrease of the parent in presence of active S9 and cofactors and $24.5 \%$ decrease with the negative control (enzymatically inactive RT-S9) within $60 \mathrm{~min}$ (Fig. 5). This abiotic rate which may be due to the abiotic cleavage of this precursor was subtracted from the biotransformation rate resulting in a final rate of $1.97 \mathrm{~mL} / \mathrm{h} / \mathrm{mg}$ protein. In the RT-S9 test, the major isomers of Scentaurus ${ }^{\mathrm{TM}}$ Clean were quantified to- gether. The $\log \mathrm{K}_{\mathrm{ow}}$ determination ${ }^{[25]}$ revealed a range from 5.3 to 6.6 for the major isomers, illustrating the relative hydrophobicity of the test item. Thus, using this range of values as input for the IVIVE model, the BCF predicted with the current IVIVE model is $195-285 \mathrm{~L} / \mathrm{kg}$ using an assumed $f_{\mathrm{U}}=1.0$, while the predicted BCF is $1341-1548 \mathrm{~L} / \mathrm{kg}$ when accounting for differential binding to protein in the in vitro test and in vivo $\left(f_{\mathrm{U}}\right.$ calculated). In contrast, the predicted BCFs assuming no biotransformation ranged from $8075\left(\log \mathrm{K}_{\mathrm{w}} 5.3\right)$ to $\sim 21,000 \mathrm{~L} / \mathrm{kg}\left(\log \mathrm{K}_{\mathrm{ow}} 6.6\right)$ indicating that especially for high $\log \mathrm{K}_{\mathrm{ow}}$ chemicals, biotransformation can substantially lower the predicted BCF. However, as indicated above, the $f_{\mathrm{U}}$ calculated approach may be more conservative than the $f_{\mathrm{U}}$ $=1.0$ approach. Nevertheless, based on both modeling assumptions, the bioaccumulation threshold of ECHA is not reached for Scentaurus ${ }^{\mathrm{TM}}$ Clean, and biotransformation by fish liver enzymes appears to mitigate the potential of this highly lipophilic molecule to bioaccumulate.

Finally, Scentaurus ${ }^{\mathrm{TM}}$ Clean was tested in the ready biodegradation test. Based on a mineralization of $62 \%$ after 28 days Scentaurus $^{\mathrm{TM}}$ Clean is readily biodegradable. According to the OECD guidance document, ${ }^{[1]}$ the 10 -day window was not applied to interpret the results of the test, as Scentaurus ${ }^{\top M}$ Clean consists of "constituents with different chain-lengths, degree and/or site of branching or stereo-isomers", even in its most purified commercial form. In this case it can reasonably be anticipated that a sequential biodegradation of the individual structures is taking place and the 10-day window should not be applied to interpret the results of the test. Next to the fact that Scentaurus ${ }^{\mathrm{TM}}{ }^{\text {Clean is a }}$ mixture of isomers, it is likely that mass transfer effects strongly influence the shape of the biodegradation curve for this very poorly water-soluble substance. The OECD 301F test is performed at test substance concentrations greatly exceeding those observed in the environment, and, a minimum of $50 \mathrm{mg}$ of theoretical oxy- 


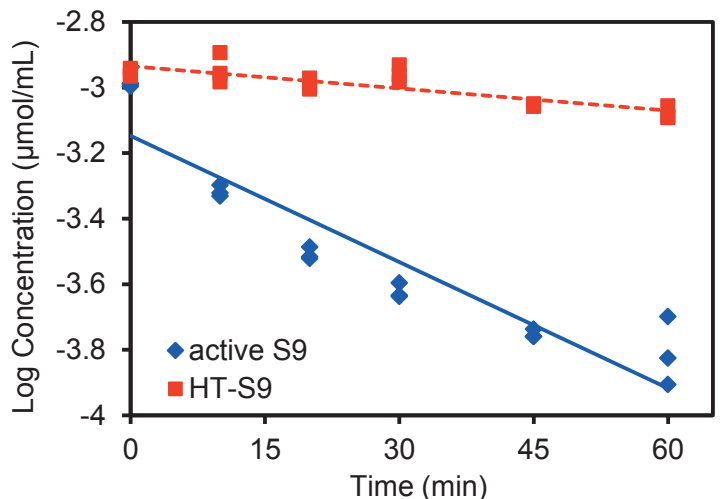

Fig. 5. Biotransformation of Scentaurus Clean ${ }^{\mathrm{TM}}$ in trout liver S9 subcellular fractions (RT-S9). Closed blue diamonds, active RT-S9 fractions with cofactors added; closed red squares, enzymatically inactive (heattreated) RT-S9 (HT-S9) fractions. Note: A linear decrease over time was observed in the negative control with HT-S9 indicating abiotic losses probably due to adsorption phenomena for this highly lipophilic chemical or due to abiotic cleavage of the precursor. Thus, this abiotic rate is subtracted from the overall rate to determine the final biotransformation rate.

gen demand per litre is stipulated in the test guideline. This is required to permit differentiation between the samples containing test item and sludge inoculum from those 'blank' incubates containing only sludge inoculum. Thus, the test on Scentaurus ${ }^{\mathrm{TM}}$ Clean was conducted at $20 \mathrm{mg} / \mathrm{L}$, which is 500 -fold above the water solubility. As bacteria can only work against the dissolved chemicals in water, the speed of dissolution will be a limiting factor for biodegradation kinetics thus determining the degradation rate. Still considering this limitation, a very efficient degradation is observed for Scentaurus ${ }^{\mathrm{TM}}$ Clean. The overall PBT profile of Scentaurus ${ }^{\mathrm{TM}}$ Clean is summarized in Table 2.

\section{Outlook: Towards Full Regulatory Acceptance and Environmentally Safe Chemicals}

Standardization of alternatives to animal testing, namely for the two tests discussed here, has gone a long way over the last five years and the international implementation as OECD guidelines is completed or is progressing. Yet, with the adoption of an OECD TG, the process is not yet finalized, as only acceptance of the results by regulatory bodies around the globe guarantees that no animal tests need to be conducted. To facilitate regulatory acceptance, building trust in the methods and their respective output is an essential element. A key aspect for building confidence is to evaluate the applicability domain of the methods, i.e. the chemical space where prediction is likely to be sufficiently accurate. As summarized in this review, we have invested significant resources to benchmark the existing in vivo data with data from the two in vitro tests, ${ }^{[27,31]}$ and we have demonstrated that both fish acute toxicity and bioaccumulation of fragrance ingredients can be accurately predicted with these new methods. While the outcome of the RTgill-W1 assay can directly be translated into a predicted fish $\mathrm{LC}_{50}$ value by Eqn. (1), a more sophisticated IVIVE model has been proposed to translate an in vitro biotransformation rate into a BCF. ${ }^{[23]}$ This model is still subject to a number of uncertainties. Thus, we have carefully assessed the sources of these uncertainties, which we will report in a detailed publication (Laue et al., manuscript in preparation).

Yet, as shown by the case studies provided here, the fruits of investing into mechanistic and in vitro toxicology are not solely for the replacement of animal tests. The application of an integrated testing platform with rapid tests early in the discovery pipeline also allows identification of promising molecules with a safe environmental profile. This is clearly demonstrated by the two recent market introductions, Pomelol ${ }^{\circledR}$ and Scentaurus ${ }^{\mathrm{TM}}$
Clean, which are readily biodegradable and efficiently biotransformed in the RT-S9 assay. The need to reduce laboratory testing on vertebrate species is a global issue recognized by industry, regulatory and non-governmental organizations alike. Hopefully, the $6^{\text {th }} \mathrm{R}$ (regulatory acceptable) for these assays, which have already been demonstrated to be relevant and reproducible, is approaching rapidly.

\begin{tabular}{ll}
\multicolumn{2}{l}{ Abbreviations } \\
BCF & Bioconcentration factor (L/kg) \\
IVIVE & In vitro-in vivo extrapolation \\
EC $_{50}$ & Half maximal Effect Concentration (mg/L) \\
ECHA & European Chemicals Agency \\
FET & Fish Embryo Acute Toxicity Test \\
$f_{\mathrm{U}}$ & Fraction unbound; binding term used to correct for bind- \\
& ing effects in vitro and in plasma (in vivo) \\
GC & Gas Chromatography \\
GLP & Good Laboratory Practice \\
$k_{\mathrm{B}}$ & Whole-body biotransformation rate constant $($ also referred \\
& to as whole-body metabolism rate constant $\left(k_{\mathrm{MET}}\right.$, $\left.^{-1}\right)$ \\
$k_{\mathrm{E}}$ & Fecal egestion rate constant $\left(\mathrm{d}^{-1}\right)$ \\
$k_{1}$ & Gill uptake rate constant $(\mathrm{L} / \mathrm{kg} / \mathrm{d})$ \\
$k_{2}$ & Gill elimination rate constant $\left(\mathrm{d}^{-1}\right)$ \\
LC & Liquid Chromatography \\
LC & Half maximal Lethal Concentration (mg/L) \\
Log K & $n$-Octanol water partition coefficient \\
MS & Mass spectrometry \\
OECD & Organisation for Economic Co-operation and \\
& Development \\
PB & PrestoBlue ${ }^{\circledR}$ assay \\
PBT & Persistent, bioaccumulative, toxic \\
QSAR & Quantitative Structure-Activity Relationship \\
REACH & Registration, Evaluation, Authorization and Restriction \\
& of Chemicals \\
RT-S9 & Rainbow trout liver S9 sub-cellular fraction \\
RTgill-W1 & Gill cell line from rainbow trout \\
TG & Test Guideline \\
ThOD & Theoretical Oxygen Demand \\
&
\end{tabular}

\section{Acknowledgements}

The authors thank Dr. Karen Jenner for input and correction of the manuscript.

Received: December 3, 2019

[1] OECD, Revised Introduction to the OECD Guidelines for Testing of Chemicals, Section 3, 'OECD Guidelines for the Testing of Chemicals', OECD Publishing, 2006, doi: 10.1787/9789264030213-en.

[2] OECD, Test No. 305, 'OECD Guidelines for Testing of Chemicals', OECD Publishing, 2012, doi: 10.1787/9789264185296-en.

[3] ECHA, Guidance on Information Requirements and Chemical Safety Assessment Chapter R.11: 'PBT/vPvB assessment'; Version 3.0, 2017, doi: $10.2823 / 128621$

[4] J. W. Nichols, I. R. Schultz, P. N. Fitzsimmons, Aquat. Toxicol. 2006, 78, 74. doi: 10.1016/j.aquatox.2006.01.017.

[5] OECD, Test No. 201, 'OECD Guidelines for the Testing of Chemicals', OECD Publishing, 2011, doi: 10.1787/9789264069923-en.

[6] OECD, Test No. 202, 'OECD Guidelines for the Testing of Chemicals', OECD Publishing, 2004, doi: 10.1787/9789264069947-en.

[7] OECD, Test No. 203, 'OECD Guidelines for the Testing of Chemicals', OECD Publishing, 2019, doi: 10.1787/9789264069961-en.

[8] OECD, No. 126, 'Short Guidance on the Treshold Approach for Acute Fish Toxicity, Series on Testing and Assessment', OECD Publishing, 2010. https://www.oecd.org/chemicalsafety/ testing/40985084.pdf.

[9] OECD, Test No. 236, 'OECD Guidelines for the Testing of Chemicals', OECD Publishing, 2013, doi: 10.1787/9789264203709-en.

[10] S. E. Belanger, J. M. Rawlings, G. J. Carr, Environ. Toxicol. Chem. 2013, 32, 1768, doi: 10.1002/etc.2244.

[11] A. Lillicrap, S. Belanger, N. Burden, D. D. Pasquier, M. R. Embry, M. Halder, M. A. Lampi, L. Lee, T. Norberg-King, B. A. Rattner, K. Schirmer, P. Thomas, Environ. Toxicol. Chem. 2016, 35, 2637, doi: 10.1002/etc.3603.

[12] Joint Report ECHA and UBA, 2018, Expert Workshop on the potential regulatory application of the Fish Embryo Acute Toxicity (FET) Test under REACH, CLP and the BPR, https://echa.europa.eu/documents/10162/13630/ 
fet_workshop_proceedings_en.pdf/a987ccab-5d4a-a226-2a73-994be484ca8d.

[13] ECHA, Current status of regulatory applicability under the REACH, CLP and BiocidalProductsregulations,EuropeanChemicalsAgency, 2017, https://echa. europa.eu/documents/10162/22931011/ non_animal_approcches_en.pdf/ 87ebb68f-2038-f597-fc33-f4003e9e7d7d.

[14] W. M. S. Russell, R. L. Burch, 'The principles of humane experimental technique', Wheathampstead (UK): Universities Federation for Animal Welfare, 1959.

[15] J. A. Arnot, D. Mackay, M. Bonnell, Environ. Toxicol. Chem. 2008, 27, 341, doi: 10.1897/07-310R.1.

[16] E. Papa, L. van der Wal, J. A. Arnot, P. Gramatica, Sci. Total Environ. 2014, 470-471, 1040, doi: 10.1016/j.scitotenv.2013.10.068.

[17] T. N. Brown, J. A. Arnot, F. Wania, Environ. Sci. Technol. 2012, 46, 8253, doi: 10.1021/es301182a.

[18] J. Nichols, K. Fay, M. J. Bernhard, I. Bischof, J. Davis, M. Halder, J. Hu, K. Johanning, H. Laue, D. Nabb, C. Schlechtriem, H. Segner, J. Swintek, J. Weeks, M. Embry, Toxicol. Sci. 2018, 164, 563, doi: 10.1093/toxsci/kfy113.

[19] OECD, Test No. 319A, 'OECD Guidelines for the Testing of Chemicals', OECD Publishing, 2018, doi: 10.1787/2074577x.

[20] OECD, Test No. 319B, 'OECD Guidelines for the Testing of Chemicals', OECD Publishing, 2018, doi: $10.1787 / 2074577 x$.

[21] OECD, No. 280, 'Guidance Document on the determination of in vitro intrinsic clearance using cryopreserved hepatocytes (RT-HEP) or liver S9 subcellular fractions (RT-S9) and extrapolation to in vivo intrinsic clearance', Series on Testing and Assessment, OECD Publishing, 2018.

[22] D. Hallifax, J. Foster, J. B. Houston, Pharm. Res. 2010, 27, 2150, doi: 10.1007/s11095-010-0218-3

[23] J. W. Nichols, D. B. Huggett, J. A. Arnot, P. N. Fitzsimmons, C. E. CowanEllsberry, Environ. Toxicol. Chem. 2013, 32, 1611, doi: 10.1002/etc.2219.

[24] U.S. Environmental Protection Agency, DC., 'Exposure Assessment Tool and Models, Estimation Program Interface (EPI) Suite', Version 4.1, 2013.

[25] OECD, Test No. 117, 'OECD Guidelines for the Testing of Chemicals', OECD Publishing, 2004, doi: 10.1787/9789264069824-en.

[26] B. I. Escher, C. E. Cowan-Ellsberry, S. Dyer, M. R. Embry, S. Erhardt, M. Halder, J.-H. Kwon, K. Johanning, M. T. T. Oosterwijk, S. Rutishauser, H. Segner, J. Nichols, Chem. Res. Toxicol. 2011, 24, 1134, doi: 10.1021/ tx200114y.

[27] H. Laue, H. Gfeller, K. J. Jenner, J. W. Nichols, S. Kern, A. Natsch, Environ. Sci. Technol. 2014, 48, 9486, doi: 10.1021/es500904h.
[28] P. C. von der Ohe, R. Kuhne, R. U. Ebert, R. Altenburger, M. Liess, G. Schuurmann, Chem. Res. Toxicol. 2005, 18, 536, doi: 10.1021/tx0497954.

[29] K. Tanneberger, M. Knobel, F. J. Busser, T. L. Sinnige, J. L. Hermens, K. Schirmer, Environ. Sci. Technol. 2013, 47, 1110, doi: 10.1021/es303505z.

[30] M. Fischer, S. E. Belanger, P. Berckmans, M. J. Bernhard, L. Blaha, D. E. Coman Schmid, S. D. Dyer, T. Haupt, J. L. M. Hermens, M. T. Hultman, H. Laue, A. Lillicrap, M. Mlnarikova, A. Natsch, J. Novak, T. L. Sinnige, K. E. Tollefsen, V. von Niederhausern, H. Witters, A. Zupanic, K. Schirmer, Toxicol. Sci. 2019, 169, 353, doi: 10.1093/toxsci/kfz057.

[31] A. Natsch, H. Laue, T. Haupt, V. von Niederhausern, G. Sanders, Environ. Toxicol. Chem. 2018, 37, 931, doi: 10.1002/etc.4027.

[32] A. Natsch, R. Emter, Altern. Lab. Anim. 2016, 44, 443, doi: 10.1177/026119291604400513.

[33] OECD, Test No. 442D, 'OECD Guidelines for the Testing of Chemicals', OECD Publishing, 2018, doi: 10.1787/9789264229822-en.

[34] OECD, Test No. 301, 'OECD Guidelines for the Testing of Chemicals', OECD Publishing, 1992, doi: 10.1787/9789264070349-en.

[35] ECHA, https://echa.europa.eu/registration-dossier/-/registered-dossier/ 20604, accessed November 18, 2019.

[36] ECHA, https://echa.europa.eu/registration-dossier/-/registered-dossier/ 21470, accessed November 18, 2019.

[37] OECD, Test No. 23, 'OECD Guidelines for the Testing of Chemicals', OECD Publishing, 2019, doi: 10.1787/0ed2f88e-en.

[38] OECD, Test No. 105, 'OECD Guidelines for the Testing of Chemicals', OECD Publishing, 1995, doi: 10.1787/9789264069589-en.

[39] J. A. Arnot, F. A. P. C. Gobas, QSAR Comb. Sci. 2003, 22, 337, doi: 10.1002/ qsar.200390023.

\section{License and Terms}

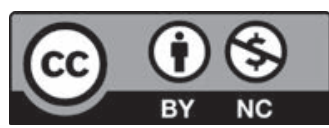

This is an Open Access article under the terms of the Creative Commons Attribution License CC BY_NC 4.0. The material may not be used for commercial purposes.

The license is subject to the CHIMIA terms and conditions: (http:// chimia.ch/component/sppagebuilder/?view=page\&id=12).

The definitive version of this article is the electronic one that can be found at doi:10.2533/chimia.2020.168 